\title{
Excellent results up to 20 years with the Ross operation, albeit with some sobering
}

\author{
Hans-Hinrich Sievers, MD
}

\footnotetext{
From the Department of Cardiac and Thoracic Vascular Surgery, University of Lübeck, Lübeck, Germany. Disclosures: Author has nothing to disclose with regard to commercial support.

Received for publication June 25, 2018; revisions received June 25, 2018; accepted for publication June 25, 2018; available ahead of print Aug 8, 2018.

Address for reprints: Hans-Hinrich Sievers, MD, Department of Cardiac and Thoracic Vascular Surgery, University of Lübeck, Ratzeburger Allee 160, 23538 Lübeck, Germany (E-mail: hanshsievers@googlemail.com). J Thorac Cardiovasc Surg 2019;157:209-10

$0022-5223 / \$ 36.00$

Copyright (C) 2018 by The American Association for Thoracic Surgery

https://doi.org/10.1016/j.jtcvs.2018.06.074
}

Replacement of the diseased aortic valve in young and middle-aged patients is still controversial. Restoration of normal anatomic and functional conditions theoretically may warrant optimal results. At first glance, it seems relatively easy to construct three mobile leaflets. Looking deeper into the fascinating physiology of the semilunar leaflets, however, it becomes obvious that we are unable to create a living normal semilunar valve leaflet. We use artificial substitutes, which are much better than the diseased valve but still not optimal and not satisfactory, leaving the patient with shortcomings that may have a tremendous effect on mortality, morbidity, lifestyle, and quality of life. Every effort to reduce these drawbacks is mandatory. The Ross procedure seems to be an elegant alternative, because autologous, living valve tissue is used. Nevertheless, it is a double valve operation with its own potential complications.

In their publication in this issue of the Journal, David and colleagues $^{1}$ from Toronto again add tremendously to our understanding of the long-term results after the Ross procedure. The Toronto results are excellent even after 20 years, with a reoperation incidence of $16.8 \%$ and a "normal" survival, ${ }^{2}$ with no difference between the surgical techniques of root replacement versus subcoronary. These results are invaluable for judgement of the Ross principle. A more differentiated classification of valve performance might even refine the evaluation. ${ }^{3}$ Somewhat sobering is the observation that there is a slow deterioration of valve function with time, as has also been shown by my group, ${ }^{3}$ for both the autograft and homograft. For the autograft, this may be due to excision-related disruption of blood supply, nerves, and lymphatic vessels; acute subjection to systemic pressure; aging; surgically altered geometry; or genetically "weak" tissue, especially in patients with preoperative aortic insufficiency and bicuspid aortic valve, hindering perfect adaptation. Patients with preoperative aortic insufficiency are at risk for earlier autograft degeneration, ${ }^{1,3}$ although the reoperation rate in these patients is not (yet?) significantly increased. Patients with preoperative aortic stenosis are the best candidates; not only is the annular diameter smaller than that of patients with aortic

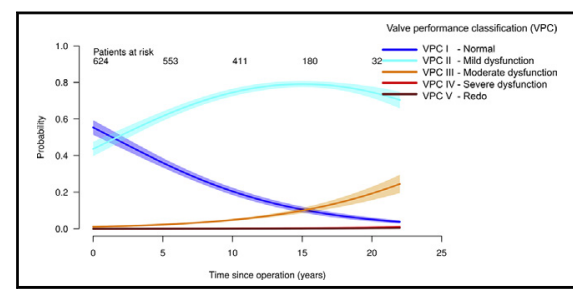

Excellent but slowly declining valve performance after the subcoronary Ross operation.

Central Message

The perfect Ross operation yields excellent results out to 20 years in selected patients, albeit with a slow valve degeneration, especially in patients with preoperative aortic insufficiency.

See Article page 201.

insufficiency, but also the tissue seems stronger, indicating 2 different genetic pathways.

There is accumulating evidence that the Ross procedure cannot achieve complete physiologic conditions with time, but the results are nearer to normal than the alternatives. Preconditions for excellent results are surgical expertise, including a profound understanding of the semilunar valve anatomy, and paying attention to procedural key points. These are selecting the autograft and patients (exclusion of patients with connective tissue disease, active rheumatic process, untreatable hypertension), reducing and fixing the annulus and sinotubular junction to normal size (26-28 mm), achieving appropriate coaptation with absolute parallelism and no prolapse formation of any of the 2 leaflets, and implanting the autograft annulus into the aortic annulus, thereby neutralizing annular irregularities. These may occur in patients with a bicuspid aortic valve, especially in type $1 \mathrm{~L} / \mathrm{R},{ }^{4}$ characteristically with the nadir of the noncoronary sinus deeper in the left ventricular outflow tract than those of the left and right coronary sinus (type $2 \mathrm{~L} /$ $\mathrm{R}-\mathrm{R} / \mathrm{N}$ bicuspid valve is better for Ross operation). Further reinforcement for dilation protection would be advantageous, preferably with autologous tissue such as the native aortic root.

Performed under optimal conditions, the Ross operation can provide excellent results even after 20 years, justifying its more widespread application. The Ross operation is a real surgical challenge that still carries a considerable potential to improve even results of aortic valve replacement. Cardiovascular society-conducted training programs with 
certification and proctoring favorably supported by a global Ross community may be helpful.

\section{References}

1. David TE, Ouzounian M, David CM, Lafreniere-Roula M, Manlhiot C. Late results of the Ross procedure. J Thorac Cardiovasc Surg. 2019;157:201-8.
2. David TE, David C, Woo A, Manlhiot C. The Ross procedure: outcomes at 20 years. J Thorac Cardiovasc Surg. 2014;147:85-93.

3. Sievers HH, Stierle U, Petersen M, Klotz S, Richardt D, Diwoky M, et al. Valve performance classification in 630 subcoronary Ross patients over 22 years. $J$ Thorac Cardiovasc Surg. 2018;156:79-86.e2.

4. Sievers HH, Schmidtke C. A classification system for the bicuspid aortic valve from 304 surgical specimens. J Thorac Cardiovasc Surg. 2007;133: 1226-33. 